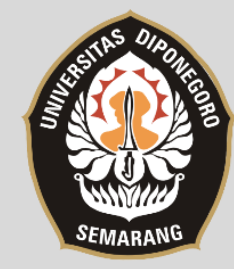

pISSN : $1829-8370$ eISSN : 2301-9069

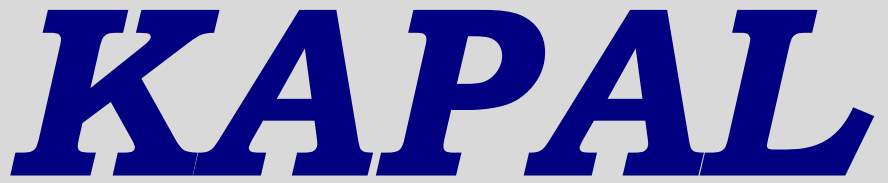

JURNAL ILMU PENGETAHUAN \& TEKNOLOGI KELAUTAN

\title{
Studi Karakteristik Resonansi Gerak Rolling Akibat Perbedaan Karakteristik Lengan Stabilitas
}

\author{
Daeng Paroka ${ }^{1 * *}$, Rosmani $^{\text {l) }}$, Syamsul Asri ${ }^{1)}$, Hamzah $^{\text {l) }}$ \\ ${ }^{1)}$ Departemen Teknik Kelautan, Fakultas Teknik, Universitas Hasanuddin \\ Jl. Poros Malino Km.6, Bontomarannu, Gowa, Sulawesi Selatan 92171
}

disubmit pada $: 13 / 02 / 19 \quad$ direvisi pada $: 26 / 02 / 19 \quad$ diterima pada $: 20 / 03 / 19$

\begin{abstract}
Abstrak
Beberapa type kapal tidak dapat memenuhi kriteria stabilitas karena perbedaan karakteristik geometri seperti kapal feri ro-ro Indonesia yang memiliki lambung timbul dan sarat yang kecil dibandingkan dengan lebar kapal. Oleh karena itu, kriteria stabilitas khusus untuk kapal dengan karakteristik geometri yang tidak terakomodir pada kriteria IMO penting untuk dikembangkan. Paper ini membahas tentang pengaruh karakteristik lengan stabilitas terhadap respon gerak roll pada gelombang samping. Hal ini merupakan langkah awal dalam pengembangan kriteria stabilitas yang berbasis karakteristik lengan stabilitas. Respon gerak berupa amplitudo resonansi sebagai fungsi frekuensi eksitasi dihitung dengan menyelesaikan persamaan gerak roll menggunakan metode multiple scale.Karakteristik lengan stabilitas divariasikan dengan tinggi metacentra serta sudut kemiringan dengan lengan stabilitas sama dengan nol tetap sama untuk semua variasi.Hasil perhitungan menunjukkan bahwa frekuensi resonansi menjadi lebih kecil dari frekuensi natural roll untuk koefisien kekakuan lebih kecil dari nol dan lebih besar dari frekuensi natural apabila koefisien tersebut lebih besar dari nol.Gerak roll tidak stabil mulai terjadi ketika amplitudo roll lebih besar dari sudut kemiringan dengan lengan stabilitas maksimum ketika rasio tinggi dan panjang gelombang sama dengan atau lebih besar dari 0.04.Untuk karakteristik lengan stabilitas kapal pada muatan penuh, ketidakstabilan gerak roll mulai terjadi pada rasio tinggi dan panjang gelombang sama dengan 0.06 .
\end{abstract}

Copyright (C) 2019, KAPAL, pISSN:1829-8370, eISSN : 2301-9069

Kata Kunci : Stabilitas, Gerak Roll, Lengan Stabilitas, Kriteria Stabilitas

\section{PENDAHULAN}

Salah satu parameter dari kriteria umum stabilitas kapal adalah karakteristik lengan stabilitas yang meliputi luasan di bawah kurva lengan stabilitas sampai sudut kemiringan 30.0 derajat dan 40.0 derajat, sudut kemiringan dengan lengan stabilitas maksimum serta sudut kemiringan dimana permukaan air sudah menyentuh bukaan di geladak utama atau sudut kemiringan dengan lengan stabilitas sama dengan nol [1]. Kriteria ini diberlakukan untuk semua kapal dengan panjang lebih besar dari 24.0 meter.

\footnotetext{
*) Penulis Korespondensi :

Email : dparoka@eng.unhas.ac.id
}

Beberapa tipe kapal sangat sulit untuk memenuhi kriteria tersebut akibat karakteristik geometri yang berbeda dengan karakteristik geometri yang dijadikan dasar penyusunan kriteria tersebut. Rasio antara lebar dan sarat yang besar serta lambung timbul yang kecil dibandingkan dengan lebar kapal mengakibatkan sudut kemiringan dengan lengan stabilitas maksimum cenderung terjadi pada sudut kurang dari 25.0 derajat [2]. Beberapa tipe kapal, khususnya kapal kayu tradisional umumnya memiliki bukaan di geladak utama yang tidak tertutup secara kedap sehingga sudut kemiringan dimana permukaan air sudah menyentuh bukaan pada geldak utama cenderung lebih kecil dari 40 atau bahkan lebih kecil dari 
30.derajat. Untuk kapal dengan karakteristik seperti ini, tidak memungkinkan untuk menghitung luasan di bawah kurva sampai 30.0 derajat atau 40.0 derajat.

Revisi kriteria stabilitas yang telah dilakukan oleh International Maritime Organization (IMO) tetap mempertahankan kriteria tersebut akan tetapi tetap memberikan peluang kepada masing-masing negara anggota mementukan sendiri kriteria stabilitas untuk kapal yang beroperasi di dalam negeri. Untuk memberikan jamiman keselamatan terhadap kapal yang beroperasi di dalam negeri tetapi tidak memungkinkan untuk menerapkan kriteria stabilitas yang sudah ada seperti kriteria stabilitas IMO, perlu dibuatkan kriteria khusus dengan tingkat keselamatan dari segi stabilitas masih dalam batas teloransi yang dapat diterima.

Salah satu parameter yang dapat digunakan dalam menentukan kondisi batas lengan stabilitas yang memungkinkan kapal dapat beroperasi dengan aman adalah performa gerak rolling khususnya pada saat beroperasi pada gelombang samping. Perbedaan karakteristik lengan stabilitas seperti tinggi metacentra (GM), luasan di bawah kurva lengan stabilitas, sudut kemiringan dengan lengan stabilitas maksimum serta sudut kemiringan dengan lengan stabilitas sama dengan nol dapat berpengaruh terhadap karakteristik gerak rolling selain faktor redaman [3], [4]. Beberapa penelitian menunjukkan bahwa perubahan karakteristik lengan stabilitas berdampak signifikan terhadap karakteristik gerak roll khususnya pada amplitudo yang cukup besar [5]. Gerak roll dapat menjadi tidak stabil dan dapak berdampak terhadap ketenggelaman kapal.

Paper ini membahas tentang pengaruh karakteristik lengan stabilitas terhadap karakteristik respon gerak roll pada gelombang samping. Hasil simulasi dan analisis yang diperoleh dapat dijadikan dasar untuk penentuan kriteria stabilitas khususnya untuk kapal dengan karakteristik geometri yang berbeda dengan yang dijadikan dasar dalam penentuan kriteria stabilitas yang digunakan saat ini. Karakteristik gerak roll sebagai fungsi dari rasio tinggi dan panjang gelombang $(H / \lambda)$ dapat dijadikan dasar untuk menentukan kondisi perairan dimana kapal masih dapat beroperasi dengan aman. Selain itu, hasil yang diperoleh dapat menjadi salah satu acuan dalam perencanaan kapal terutama dari aspek stabilitas.

\section{METODE}

Pengaruh karakteristik lengan stabilitas terhadap karakteristik gerak rolling dilakukan terhadap kapal feri ro-ro dengan ukuran utama ditunjukkan pada Tabel 1. Kapal ini memiliki rasio lebar dan sarat kapal yang lebih besar dari rasio yang dijadikan dasar penyusunan kriteria cuaca [6]. Rasio jarak vertikal titik berat terhadap permukaan air laut dengan sarat kapal juga lebih besar dari rasio yang digunakan untuk menentukan koefisien kelandaian efektif gelombang pada kriteria cuaca sehingga nilai dari koefisien tersebut menjadi lebih besar dari 1.0. Perbedaan karakteristik geometri ini mengakibatkan beberapa kapal feri ro-ro Indonesia tidak dapat memenuhi kriteria stabilitas IMO [2]. Lengan stabilitas kapal pada kondisi muatan penuh ditunjukkan pada Gambar 1.

Tabel 1. Ukuran utama kapal

\begin{tabular}{lcr}
\hline \multicolumn{1}{c}{ Dimensi } & Satuan & \multicolumn{1}{c}{ Nilai } \\
\hline Panjang antara garis tegak $(\mathrm{Lbp})$ & $\mathrm{m}$ & 50.50 \\
Lebar $(\mathrm{B})$ & $\mathrm{m}$ & 14.00 \\
Tinggi $(\mathrm{H})$ & $\mathrm{m}$ & 3.80 \\
Sarat $(\mathrm{T})$ & $\mathrm{m}$ & 2.70 \\
Titik berat vertikal $(\mathrm{KG})$ & $\mathrm{m}$ & 4.73 \\
Tinggi metacentra $(\mathrm{GM})$ & $\mathrm{m}$ & 4.23 \\
B/T & - & 5.19 \\
KG/T & - & 1.75 \\
Frekuensi natural roll $\left(\omega_{o}\right)$ & $\mathrm{rad}_{\mathrm{s}} \mathrm{s}^{-1}$ & 1.46 \\
Koefisien redaman linear $(\mu)$ & $\mathrm{s}^{-1}$ & 0.17 \\
Koefisien redaman kuadratik $(\beta)$ & $\mathrm{rad}^{-1}$ & 0.05 \\
\hline
\end{tabular}

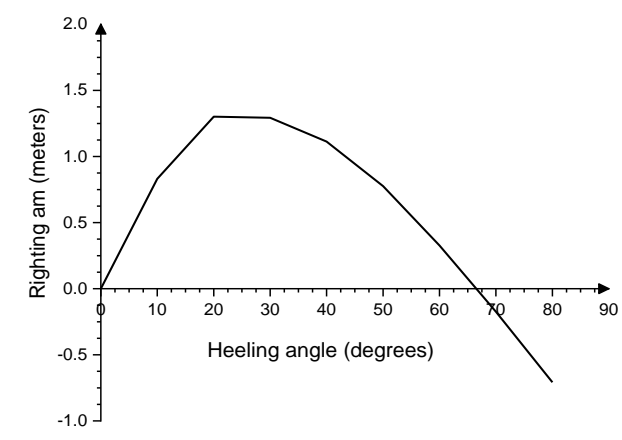

Gambar 1. Lengan stabilitas

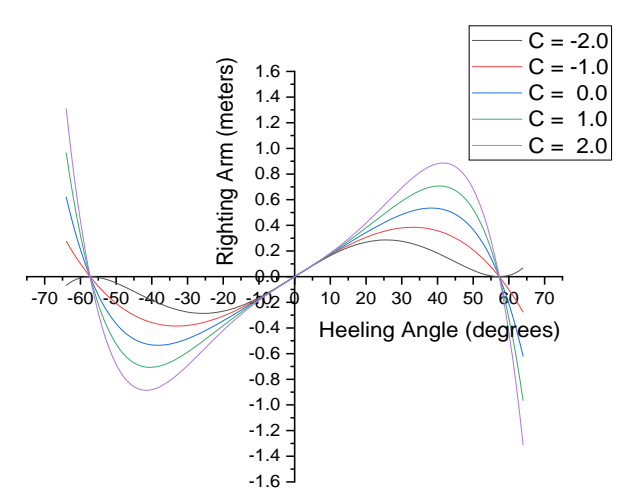

Gambar 2. Variasi karakteristik lengan stabilitas 
Untuk mendapatkan variasi karakteristik lengan stabilitas, lengan stabilitas dimodelkan dengan menggunakan persamaan polynomial order 5 dengan mempertahankan tinggi metacentra (GM) serta range stabilitas sama pada semua variasi kurva lengan stabilitas. Persamaan polynomial yang memungkinkan untuk memenuhi kondisi tersebut ditunjukkan pada persamaan (1) berikut [3]:

$$
G Z(\phi)=\phi+C \phi^{3}-(1+C) \phi^{5}
$$

Karakteristik lengan stabilitas pada persamaan (1) tergantung pada variabel $\mathrm{C}$ untuk tinggi metacentra yang sama serta sudut kemiringan dengan lengan stabilitas sama dengan nol adalah 1.0 radian (57.3 derajat). Lengan stabilitas untuk nilai koefisien $\mathrm{C}$ mulai dari -2.0 sampai +2.0 ditunjukkan pada Gambar 2 dengan karakteristik meliputi luasan di bawah kurva sampai sudut kemiringan 30 derajat dan 40 derajat serta sudut kemiringan dengan lengan stabilitas maksimum ditunjukkan pada Tabel 2 .

Tabel 2. Karakteristik lengan stabilitas

\begin{tabular}{ccccc}
\hline $\begin{array}{c}\text { Lengan } \\
\text { stabilitas }\end{array}$ & $\boldsymbol{A}_{\mathbf{0 - 3 0}}$ & $\boldsymbol{A}_{\mathbf{0 - 4 0}}$ & $\boldsymbol{\phi}_{\boldsymbol{m a x}}$ & $\boldsymbol{G Z}\left(\mathbf{3 0}^{\boldsymbol{o}}\right)$ \\
\hline $\mathrm{C}=-2$ & 0.103 & 0.104 & 25.62 & 0.276 \\
$\mathrm{C}=-1$ & 0.118 & 0.163 & 33.08 & 0.380 \\
$\mathrm{C}=0$ & 0.134 & 0.222 & 38.32 & 0.484 \\
$\mathrm{C}=1$ & 0.149 & 0.281 & 40.51 & 0.588 \\
$\mathrm{C}=2$ & 0.164 & 0.340 & 41.58 & 0.693 \\
Aktual & 0.118 & 0.135 & 33.12 & 0.381 \\
\hline
\end{tabular}

Respon gerak rolling dihitung secara numerik dengan menggunakan persamaan gerak rolling nonlinear sebagai berikut [6]:

$$
\ddot{\phi}+2 \mu \dot{\phi}+\beta \dot{\phi}|\dot{\phi}|+\delta \dot{\phi}^{3}+\omega_{o}^{2} G Z(\phi)=m(t)
$$

dimana $\mu, \beta$ dan $\delta$ adalah koefisien redaman linear, kuadratik dan kubik. $\omega_{o}$ adalah frekuensi natural dan $m(t)$ adalah momen eksitasi gelombang. Koefisien redaman ditentukan melalui pengujian model roll decay test. Amplitudo momen eksitasi gelombang dihitung dengan menggunakan persamaan sebagai berikut [7]:

$$
m_{o}=\omega_{o}^{2} \pi s r
$$

dimana $s$ adalah rasio antara tinggi gelombang $(\mathrm{H})$ dan panjang gelombang $(\lambda)$ sedangkan $r$ adalah koefisien kelandaian efektif gelombang. Rasio tinggi dan panjang gelombang tergantung pada karakteristik perairan dimana IMO menetapkan rentang nilai antara 0.02 sampai 0.10 sebagai fungsi dari periode natural gerak rolling [1]. Hal ini berarti bahwa rasio tinggi dan panjang gelombang ditentukan berdasarkan frekuensi resonansi antara gerak rolling dan gelombang. Koefisien kelandaian efektif gelombang dihitung dengan menggunakan formula kriteria cuaca IMO [1] akan tetapi koefisien tersebut ditentukan sama dengan 1.0 apabila hasil yang diperoleh dari formula tersebut lebih besar dari 1.0 [8].

Amplitudo gerak rolling dihitung dengan menyelesaikan persamaan (2) dengan menggunakan metode multiple scale. Metode ini telah banyak digunakan untuk mengamati penomena resonansi serta stabilitas gerak oleng khususnya pada saat kapal beroperasi pada gelombang samping [5], [9]. Pada metode ini, penyelesaian persamaan gerak rolling dinyatakan dengan persamaan berikut [10]:

$$
\phi=\phi_{0}\left(T_{0}, T_{1}, T_{2} \ldots\right)+\epsilon \phi_{1}\left(T_{0}, T_{1}, T_{2} \ldots\right)+\cdots
$$

dimana $\epsilon$ adalah faktor skala yang menentukan besaran dari respon gerak rolling. $T_{0}, T_{1}, T_{2}$ menyatakan skala waktu berdasarkan hubungan $T_{0}=t, T_{1}=\epsilon t$ dan $T_{2}=\epsilon^{2} t$. Dengan demikian maka turunan parsial $T_{n}$ terhadap waktu dapat dinyatakan sebagai berikut:

$$
\frac{d}{d t}=\frac{d T_{0}}{d t} \frac{\partial}{\partial T_{0}}+\frac{d T_{1}}{d t} \frac{\partial}{\partial T_{1}}+\cdots=D_{0}+\epsilon D_{1}+\cdots
$$

$$
\frac{d^{2}}{d t^{2}}=D_{0}{ }^{2}+2 \epsilon D_{0} D_{1}+\epsilon^{2}\left(D_{1}{ }^{2}+2 D_{0} D_{2}\right)+\cdots
$$

dimana:

$$
D_{0}=\frac{\partial}{\partial T_{0}} ; D_{1}=\frac{\partial}{\partial T_{1}} ; D_{2}=\frac{\partial}{\partial T_{2}}
$$

Substitusi persamaan (3) - (6) ke dalam persamaan (2) diperoleh persamaan sebagai berikut:

$$
\begin{aligned}
& D_{0}^{2} \phi_{0}+\omega_{o}^{2} \phi_{0}=0 \\
& D_{1}{ }^{2} \phi_{1}+\omega_{o}{ }^{2} \phi_{1}=-2 D_{0} D_{1} \phi_{0}-2 \alpha_{E} D_{0} \phi_{0} \\
& -a_{3} \phi_{0}{ }^{3}-a_{5} \phi_{0}{ }^{5} \\
& +m_{o} \sin \left(\omega_{0} T_{0}+\sigma T_{1}\right)
\end{aligned}
$$

dimana $\sigma$ merupakan parameter yang menunjukkan frekuensi eksitasi relatif terhadap frekuensi natural. Nilai $\sigma$ lebih kecil dari nol 
untuk frekuensi eksitasi lebih kecil dari frekuensi natural roll, sebaliknya, frekuensi eksitasi lebih besar dari frekuensi natural roll ditunjukkan dengan nilai $\sigma$ lebih besar dari nol. Apabila respon gerak oleng, $\phi_{0}$ pada persamaan (7) dan (8) dinyatakan dengan persamaan berikut:

$$
\phi_{0}=A\left(T_{1}\right) \exp \left(i \omega_{0} T_{0}\right)+\bar{A}\left(T_{1}\right) \exp \left(-i \omega_{0} T_{0}\right)
$$

dimana:

$$
\begin{gathered}
A\left(T_{1}\right)=\frac{a}{2} \exp (i \beta) \\
\bar{A}\left(T_{1}\right)=\frac{a}{2} \exp (-i \beta)
\end{gathered}
$$

maka penyelesaian persamaan (8) dapat dituliskan sebagai berikut:

$$
\begin{gathered}
a^{\prime}=-\alpha_{E} a+\frac{m_{o}}{2 \omega_{o}} \sin \gamma \\
a \gamma^{\prime}=\sigma a-\frac{3}{8} \frac{a_{3}}{\omega_{o}} a^{3}-\frac{10}{32} \frac{a_{5}}{\omega_{o}} a^{5}+\frac{m_{o}}{2 \omega_{o}} \cos \gamma
\end{gathered}
$$

dimana:

$$
\gamma=\sigma T_{1}-\beta
$$

dimana $a$ adalah amplitudo gerak roll, $\beta$ adalah sudut phase gerak roll dan $\sigma$ adalah frekuensi eksitasi. $a_{3}$ dan $a_{5}$ adalah koefisien polynomial lengan stabilitas dimana $a_{3}=C$ dan $a_{5}=$ $-(1+C)$. Penyelesaian persamaan (12) dan persamaan (13) pada kondisi steady state, dimana $a^{\prime}=0$ dan $\gamma^{\prime}=0$, ditunjukkan pada persamaan (15) dan (16). Frekuensi eksitasi, $\sigma_{1}$ dan $\sigma_{2}$ merupakan fungsi dari frekuensi gelombang dan frekuensi natural.

$$
\begin{aligned}
\sigma_{1}=a^{2}\left(\frac{3}{8} \frac{a_{3}}{\omega_{o}}+\right. & \left.\frac{10}{32} \frac{a_{5}}{\omega_{o}} a^{2}\right) \\
& +\left(\frac{m_{o}^{2}}{4 \omega_{o}^{2} a^{2}}-\alpha_{E}^{2}\right)^{0.5} \\
\sigma_{2}=a^{2}\left(\frac{3}{8} \frac{a_{3}}{\omega_{o}}+\right. & \left.\frac{10}{32} \frac{a_{5}}{\omega_{o}} a^{2}\right) \\
& -\left(\frac{m_{o}^{2}}{4 \omega_{o}^{2} a^{2}}-\alpha_{E}^{2}\right)^{0.5}
\end{aligned}
$$

Stabilitas dari respon steady state gerak rolling dapat diperoleh dengan memberikan simpangan kecil terhadap penyelesaian persamaan gerak rolling yang ditunjukkan pada persamaan (15) dan persamaan (16). Jika amplitudo rolling dinyatakan dengan:

$$
a=a_{0}+a_{1}
$$

dan sudut phase respon gerak rolling dinyatakan dengan:

$$
\gamma=\gamma_{0}+\gamma_{1}
$$

dimana $a_{1}$ dan $\gamma_{1}$ adalah simpangan yang diberikan terhadap amplitudo awal, $a_{0}$ dan sudut phase awal, $\gamma_{0}$, persamaan steady state response dengan gangguan yang diberikan dapat dinyatakan sebagai berikut:

$$
\begin{gathered}
a_{1}^{\prime}=-\alpha_{E} a_{1}+\left(-\sigma a_{0}+\frac{3}{8} \frac{a_{3}}{\omega_{o}} a_{0}^{3}\right. \\
\left.+\frac{10}{32} \frac{a_{5}}{\omega_{o}} a_{0}^{5}\right) \gamma_{1} \\
\gamma_{1}^{\prime}=\frac{a_{1}}{a_{0}}\left(\sigma-\frac{9}{8} \frac{a_{3}}{\omega_{o}} a_{0}^{2}-\frac{50}{32} \frac{a_{5}}{\omega_{0}} a_{0}^{4}\right)-\alpha_{E} \gamma_{1}
\end{gathered}
$$

Persamaan (19) dan persamaan (20) adalah persamaan diferensial orde satu yang dapat dinyatakan dengan model matematika sistem dinamis sebagai berikut:

$$
x^{\prime}=A x
$$

dimana $x=[a, \gamma]^{T}$ dan $A$ adalah matriks dengan komponen koefisien dari persamaan (19) dan persamaan (20). Stabilitas respon gerak rolling dapat diidentifikasi berdasarkan nilai eigen, $\lambda$ dari matriks $A$.

$$
\left|\begin{array}{cc}
-\alpha_{E}-\lambda & X \\
Y & -\alpha_{E}-\lambda
\end{array}\right|=0
$$

dimana:

$$
\begin{aligned}
& X=\left(-\sigma a_{0}+\frac{3}{8} \frac{a_{3}}{\omega_{o}} a_{0}^{3}+\frac{10}{32} \frac{a_{5}}{\omega_{o}} a_{0}^{5}\right) \\
& Y=\frac{1}{a_{0}}\left(\sigma-\frac{9}{8} \frac{a_{3}}{\omega_{o}} a_{0}^{2}-\frac{50}{32} \frac{a_{5}}{\omega_{0}} a_{0}^{4}\right)
\end{aligned}
$$

Apabila bagian real dari nilai eigen, $\lambda_{R e}<0$ maka penyelesaian steady state dari persamaan gerak rolling adalah stabil dan sebaliknya jika bagian real dari nilai eigen, $\lambda_{R e}>0$ maka penyelesaian persamaan gerak rolling adalah tidak stabil. Persamaan (22) menunjukkan bahwa stabilitas dari penyelesaian stedy state tergantung pada faktor redaman, frekuensi natural gerak 
rolling, karakteristik lengan stabilitas serta amplitudo awal gerak roll.

\section{HASIL DAN PEMBAHASAN}

Amplitudo gerak rolling sebagai fungsi dari frekuensi gelombang untuk setiap karakteristik gelombang dan lengan stabilitas ditunjukkan pada Gambar 3 - 7. Pada amplitudo gerak roll lebih kecil dari 0.10 radian, karakteristik lengan stabilitas tidak berpengaruh terhadap respon gerak roll. Hal ini disebabkan oleh lengan stabilitas pada sudut kemiringan lebih kecil dari 0.10 radian sama untuk semua karakteristik lengan stabilitas. Perubahan koefisien persamaan polynomial lengan stabilitas hanya pada bagian nonlinear orde 3 dan orde 5 sedangkan tinggi metacentra (GM) sama untuk semua karakteristik lengan stabilitas. Pengaruh karakteristik lengan stabilitas mulai terlihat pada amplitudo gerak roll lebih besar dari 0.20 radian. Pada frekuensi resonansi yang sama, amplitudo gerak roll berbeda secara signifikan. Lengan stabilitas pada sudut kemiringan 0.20 radian sudah tidak sama untuk kelima karakteristik lengan stabilitas. Makin besar perbedaan lengan stabilitas untuk setiap sudut kemiringan, perbedaan karakteristik respon resonansi juga semakin besar pada frekuensi resonanasi yang sama menjadi semakin besar.

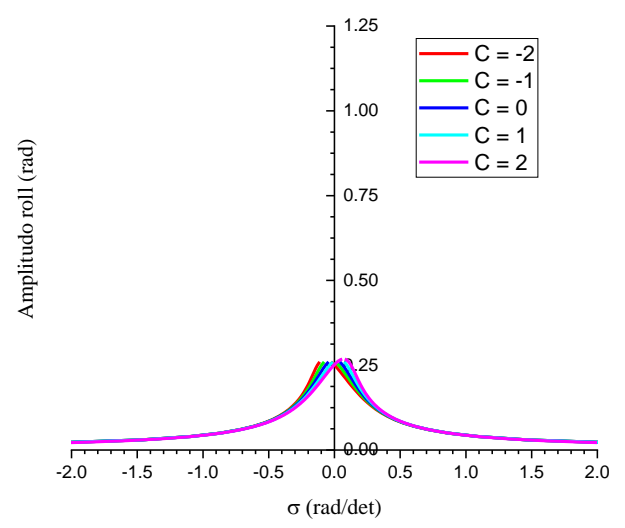

Gambar 3. Amplitudo resonansi roll untuk $\mathrm{s}=$ 0.02

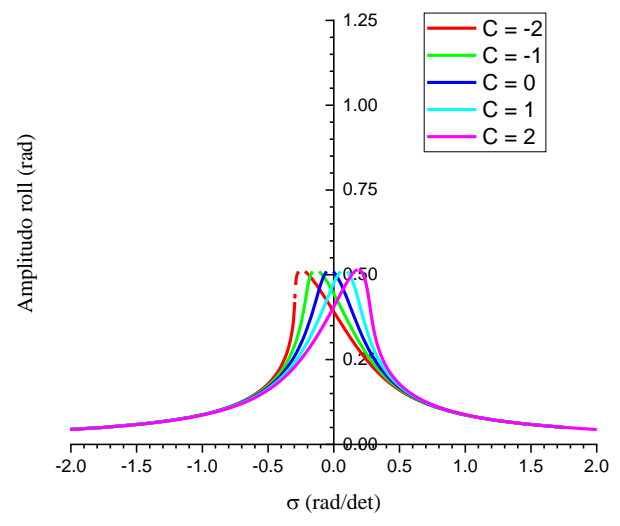

Gambar 4. Amplitudo resonansi roll untuk s = 0.04

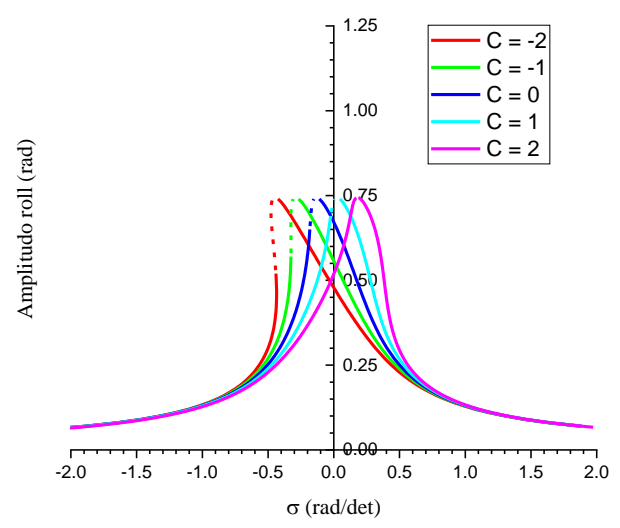

Gambar 5. Amplitudo resonansi roll untuk s = 0.06

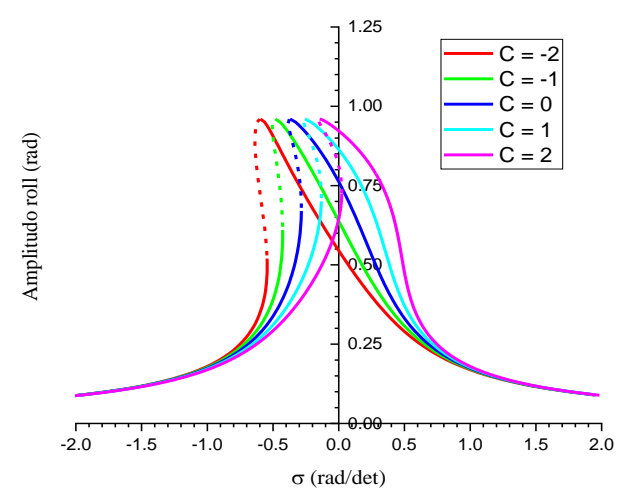

Gambar 6. Amplitudo resonansi roll untuk s = 0.08 


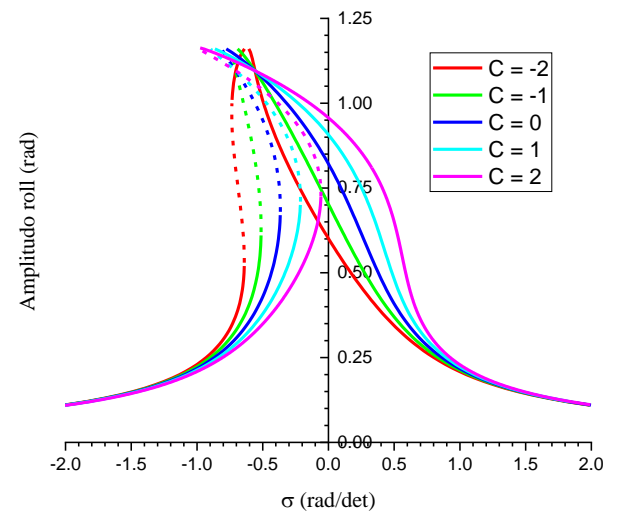

Gambar 7. Amplitudo resonansi roll untuk $\mathrm{s}=$ 0.10

Frekuensi resonansi terdefleksi ke frekuensi gelombang yang lebih kecil dari frekuensi natural roll apabila koefisien kekakuan lengan stabilitas (C) lebih kecil dari nol dan terdefleksi ke frekuensi gelombang lebih besar dari frekuensi natural jika koefisien kekakuan tersebut bernilai positif. Pada rasio tinggi dan panjang gelombang 0.08 atau lebih besar, semua kurva respon terdefleksi ke arah frekuensi yang lebih kecil dari frekuensi natural roll. Bassiouny [5] menunjukkan bahwa pada amplitudo respon lebih kecil dari sudut kemiringan dengan lengan stabilitas sama dengan nol, arah defleksi dari kurva amplitudo respon tergantung pada koefisien order 3 dari persamaan polynomial lengan stabilitas. Apabila koefisien tersebut lebih kecil dari nol maka kurva respon akan terdefleksi ke arah frekuensi yang lebih kecil dari frekuensi natural dan sebaliknya jika koefisien tersebut lebih besar dari nol maka arah defleksi ke frekuensi yang lebih besar. Arah defleksi kurva respon yang sama juga ditunjukkan oleh Bulian, et al [11] melalui simulasi numerik dan pengujian model pada rasio tinggi dan panjang gelombang 0.0125 dan 0.025 . Perubahan arah defleksi ini sangat tergantung pada perubahan lengan stabilitas terhadap sudut kemiringan atau gradien dari lengan stabilitas pada setiap sudut kemiringan. Hasil ini menunjukkan bahwa frekuensi natural roll mengalami perubahan sebagai fungsi dari amplitudo dan karakteristik lengan stabilitas. Perubahan frekuensi natural tersebut disebabkan oleh perubahan tinggi metacentra kapal akibat perubahan karakteristik lengan stabilitas pada setiap sudut kemiringan [12]. Padsa kriteria stabilitas IMO [1], tinggi metacentra ditentukan pada sudut kemiringan kecil dimana karakteristik lengan stabilitas belum berpengaruh secara signifikan terhadap karakteristik gerak roll seperti ditunjukkan pada Gambar 3.
Garis putus-putus pada setiap kurva amplitudo resonansi menunjukkan kombinasi frekuensi dan amplitudo dimana gerak roll tidak stabil. Amplitudo roll dapat berubah meskipun rasio tinggi dan panjang gelombang serta frekuensi eksitasi sama. Pada rasio tinggi dan panjang gelombang sama dengan 0.02 , gerak roll stabil pada semua frekuensi eksitasi untuk kelima karakteristik lengan stabilitas. Gerak roll yang tidak stabil mulai terjadi pada lengan stabilitas yang paling kecil, yaitu $\mathrm{C}=-2$, ketika rasio tersebut sama dengan 0.04 seperti ditunjukkan pada Gambar 4. Pada rasio tinggi dan panjang gelombang sama dengan 0.06, gerak roll yang tidak stabil terjadi pada semua karakteristik lengan stabilitas kecuali pada lengan stabilitas dengan koefisien $\mathrm{C}=2$. Pada rasio yang lebih besar, gerak oleng tidak stabil terjadi pada semua karakteristik lengan stabilitas. Range frekuensi eksitasi dengan gerak roll tidak stabil semakin besar dengan bertambahnya rasio tinggi dan panjang gelombang. Hasil ini menunjukkan bahwa nonlinearitas lengan stabilitas serta nilai lengan stabilitas pada setiap sudut kemiringan mempunyai pengaruh signifikan terhadap stabilitas gerak roll. Pada hasil perhitungan yang ditunjukkan pada Gambar $3-7$ diatas terlihat bahwa lengan stabilitas yang lebih besar mengalami ketidakstabilan gerak roll pada rasio tinggi dan panjang gelombang yang lebih besar dibandingkan dengan lengan stabilitas yang lebih kecil. Hasil yang sama ditunjukkan oleh Odabasi and Ucer [9] bahwa gerak rolling akan menjadi tidak stabil pada momen eksitasi yang lebih besar yang dapat diidentikkan dengan rasio tinggi dan panjang gelombang yang lebih besar jika faktor kelandaian efektif gelombang diasumsikan tetap.

Gerak roll tidak stabil terjadi ketika amplitudo lebih besar dari sudut kemiringan dengan lengan stabilitas maksimum. Pada kriteria stabilitas IMO, sudut kemiringan dengan lengan stabilitas maksimum harus lebih besar dari 25.0 derajat [1]. Karakteristik lengan stabilitas yang mendekati sudut maksimum dari kriteria IMO tersebut adalah lengan stabilitas dengan $\mathrm{C}=-2$ dimana lengan maksimum terjadi pada sudut kemiringan 25.62 derajat. Gerak oleng tidak stabil mulai terjadi pada rasio tinggi dan panjang gelombang sama dengan 0.04. Ketidakstabilan gerak roll dapat berakibat terjadinya penomena chaos yang dapat mengakibatkan terjadinya ketenggelaman [13]. Long, et al [14] menunjukkan bahwa resiko ketenggelaman kapal akibat ketidakstabilan gerak roll mengalami peningkatan secara signifikan ketika rasio tinggi dan panjang gelombang lebih besar dari 0.06 tetapi penomena stabilitas tersebut sudah mulai 
terjadi pada rasio sama dengan 0.045 . Oleh karena itu, dibutuhkan analisis lebih lanjut terhadap karakteristik gerak roll pada kondisi tidak stabil sebagai dasar untuk menentukan batasan sudut oleng dengan lengan stabilitas maksimum sesuai dengan kondisi perairan dimana kapal tersebut beroperasi.

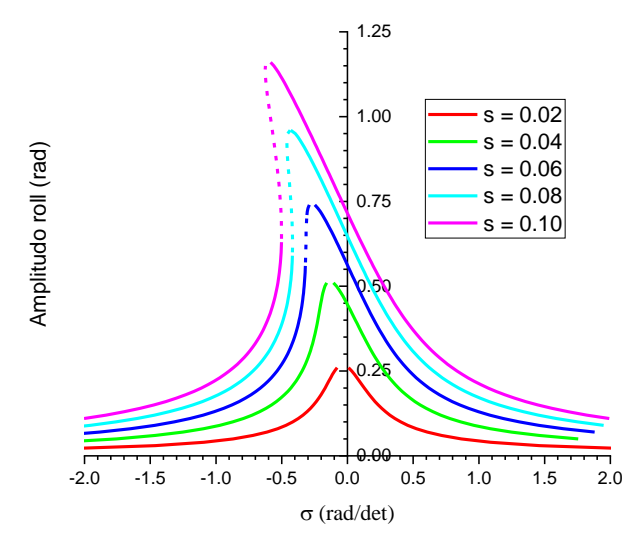

Gambar 8. Amplitudo resonansi untuk lengan stabilitas pada pemuatan penuh

Gambar 8 menunjukkan amplitudo resonansi gerak roll untuk lengan stabilitas aktual kapal yang dijadikan sampel sebagaimana ditunjukkan pada Gambar 1. Lengan stabilitas maksimum terjadi pada sudut kemiringan 33.12 derajat $(0.58$ radian). Gerak roll tidak stabil mulai terjadi pada rasio tinggi dan panjang gelombang 0.06. Hasil ini hampir sama dengan hasil yang diperoleh Long, et al [14]. Makin besar rasio tinggi dan panjang gelombang, range frekuensi dengan gerak roll tidak stabil semakin besar. Karakteristik respon gerak roll pada variasi karakteristik lengan stabilitas berbeda dengan respon pada lengan stabilitas aktual khususnya pada rasio tinggi dan panjang gelombang lebih besar dari 0.06. Sudut kemiringan dengan lengan stabilitas sama dengan nol pada variasi lengan stabilitas adalah 57.3 derajat sedangkan pada lengan stabilitas aktual sama dengan 67.5 derajat. Hasil ini menunjukkan bahwa range stabilitas juga berpengaruh terhadap karakteristik gerak roll.

Hasil analisis berdasarkan lengan stabilitas aktual menunjukkan bahwa kapal dapat beroperasi dimana gerak roll masih tetap stabil sampai pada rasio tinggi dan panjang gelombang 0.06, dimana gerak roll tidak stabil mulai terjadi tetapi hanya pada range frekuensi ekstitasi yang masih kecil sehingga kemungkinan terjadinya penomena chaos juga sangat kecil. Sesuai dengan kriteria cuaca IMO [1], kapal dengan periode natural roll lebih kecil dari 6.0 detik, rasio tinggi dan panjang gelombang yang harus digunakan untuk menghitung sudut roll adalah 0.10 lebih besar dari nilai terbesar dengan gerak roll yang stabil. Pada rasio 0.10, range frekuensi eksitasi dengan gerak roll tidak stabil cukup besar sehingga kemungkinan terjadinya ketenggelaman juga semakin besar. Untuk mengetahui karakteristik gerak roll pada kondisi respon steady state dengan gerak roll yang tidak stabil pada Gambar 8, diperlukan penelitian lebih lanjut. Selain itu, sudut roll yang diperoleh dari formula kriteria cuaca sudah mempertimbangkan faktor irregularitas dari gelombang sedangkan yang diperoleh pada perhitungan yang dikembangkan belum mempertimbangkan faktor tersebut. Respon yang diperoleh adalah amplitudo gerak roll pada gelombang reguler dengan karakteristik berupa frekuensi eksitasi serta rasio tinggi dan panjang gelombang.

\section{KESIMPULAN}

Pengaruh karakteristik lengan stabilitas terhadap respon gerak roll sebuah kapal feri ro-ro telah dianalisis dimana respon gerak roll dihitung dengan menggunakan metode multiple scale dengan rasio tinggi dan panjang gelombang mulai 0.02 sampai 0.10. Hasil simulasi numerik menunjukkan bahwa frekuensi resonansi gerak roll menjadi lebih kecil dari frekuensi natural untuk jika koefisien kekakuan dari lengan stabilitas lebih kecil dari nol dan menjadi lebih besar dari frekswensi natural apabila koefisien tersebut lebih besar dari nol sebagai akibat dari perubahan frekuensi natural pada sudut roll yang besar. Jika amplitudo gerak roll lebih besar dari sudut kemiringan dengan lengan stabilitas maksimum, frekuensi resonansi cenderung lebih kecil dari nol tergantung pada gradien lengan stabilitas terhadap sudut kemiringan pada sudut kemiringan dengan lengan stabilitas sama dengan nol.

Gerak roll tidak stabil mulai terjadi ketika amplitudo lebih besar dari sudut kemiringan dengan lengan stabilitas maksimum, yang mana mulai terjadi pada rasio tinggi dan panjang gelombang 0.04 pada lengan stabilitas dengan koefisien kekakuan $\mathrm{C}=-2$. Makin besar amplitudo roll, range frekuensi eksitasi dengan gerak roll tidak stabil semakin besar. Pada lengan stabilitas aktual kapal, gerak roll tidak stabil mulai terjadi pada rasio tinggi dan panjang gelombang 0.06 dengan range frekuensi eksitasi yang masih kecil kecil. Pada rasio tinggi dan panjang gelombang yang lebih kecil, kapal dapat beroperasi pada gelombang samping dengan aman dimana gerak roll tetap stabil.

Investigasi lebih lanjut penting untuk dilakukan sehubungan dengan karakteristik gerak roll pada amplitudo dengan gerak roll yang tidak 
stabil khususnya untuk mengamati kemungkinan terjadinya ketenggelaman akibat kehilangan stabilitas atau penomena chaos yang dapat berdampak terhadap ketenggalaman. Selain faktor karakteristik lengan stabilitas, pengaruh karakteristik redaman juga perlu untuk diamati lebih lanjut untuk dapat menentukan kombinasi redaman dan karakteristik lengan stabilitas yang memungkinkan kapal dapat beroperasi dengan aman sesuai dengan kondisi lingkungan operasi.

\section{UCAPAN TERIMA KASIH}

Paper ini merupakan bagian dari hasil penelitian yang dilaksanakan dengan pendanaan dari Universitas Hasanuddin melalui skim Penelitian Berbasis Benua Maritim Indonesia Spesifik (BMIS) dengan kontrak nomor: 3084/UN4.1.2/PL.00.00/2018. Data kapal yang digunakan pada penelitian ini adalah kapal yang dibangun di PT. Industri Kapal Indonesia (Persero). Penulis menyampaikan terima kasih kepada kedua institusi tersebut atas dukungan yang diberikan dalam pelaksanaan penelitian tersebut. Penulis juga menyampaikan terima kasih kepada Sahuddin dan Muhammad Ilham, alumni Teknik Perkapalan Unhas yang telah membantu melaksanakan pengujian model roll decay untuk mendapatkan faktor redaman yang digunakan untuk simulasi.

\section{DAFTAR PUSTAKA}

[1] International Matirime Organization, International Code on Intact Stability Resolution MSC 267 (85), London: IMO, 2008.

[2] D. Paroka, "Karakteristik Geometri dan Pengaruhnya Terhadap Stabilitas Kapal Feri Ro-Ro Indonesia," KAPAL, vol. 15, pp. 1 8, 2018.

[3] Spyrou, K.J., "A Basis for Developing a Rational Alternative to the Weather Criterion: Problem and Capabilities," in Contemporary Ideas on Ship Stability and Capsizing in Waves, London: Springer, Lpp. 25 - 46, 2011.

[4] Odabasi, A.Y., "A Note on the Conceptual Understanding of the Stability Theory of Ships," in Contemporary Ideas on Ship Stability, Oxford: Elsevier Science Ltd., UK, pp. $27-46,2000$.

[5] A.F. El-Bassiouny, "Nonlinear Rolling of a Biased Ship in a Regular Beam Wave under
External and Parametric Excitations," $A$ Journal of Physical Science, vol. 62, pp. 573 - 586, 2007.

[6] International Maritime Organization., "Interim Guidelines for Alternative Assessment of Weather Criterion: Document MSC.1/Circ.1200”, London: IMO, 2006.

[7] Francescutto, A., and Contento, G., "The Mathematical Modelling of Large Amplitude Rolling in Beam Waves", in Contemporary Ideas on Ship Stability, Oxford: Elsevier Science Ltd., 2000, pp. $125-135$.

[8] Francescutto, A., "Intact Stability Criteria of Ships - Past, Present and Future", Proceedings of the 12th International Conference on the Stability of Ships and Ocean Vehicles. Glasgow, UK. $14-19$ June 2011, pp. 1199 - 1209.

[9] Odabasi, A.Y., E. Ucer, “ Effect of Initial Bias on the Roll Response and Stability of Ships in Beam Seas," in Contemporary Ideas on Ship Stability and Capsizing in Waves, London: Springer, Lpp. 119 - 140, 2011.

[10] A.H. Nayfeh, D.T. Mook, "Nonlinear Oscillation," Weinheim: WILEY-VCH Verlag GmbH \& Co., Deutsche, Germany, 2004.

[11] G. Bulian, A. Francescutto, F. Fucile, "An Experimental Investigation in the Framework of the Alternative Assessment for the IMO Weather Criterion," Proceedings of the HYDRALAB III Joint User Meeting, Hannover, February 2010.

[12] W. Wawrzynski, P. Krata, "Method for Ship's Rolling Period Prediction with Regard to Non-linearity of GZ Curve," Journal of Theoretical and Applied Mechanis, vol. 54, pp. 1329 - 1343, 2016.

[13] S. Li, K. Wang., "Chaos Analysis of Ship Rolling Motion in Stochastic Beam Seas," Journal of Vibroengineering, vol. 19, pp. 6403 - 6412, 2017.

[14] Z.J. Long, S.K. Lee, H.S. Choi, "Risk Evaluation of Ship Dynamic Stability in Regular Waves," Jounrla of Marine Science and Technology, vol. 18, pp. 530 - 536, 2010. 